\title{
The Learning of Congruent and Incongruent Collocations Utilizing Dynamic Assessment
}

\author{
Mohammad R. Hashemi \\ Kharazmi University \\ Raziye Eskandari \\ Kharazmi University
}

The present study investigated the effect of dynamic assessment on the learning of congruent and incongruent collocations among Iranian lower-intermediate EFL learners. Forty female students participated in this quasi-experimental study. The experimental group was exposed to dynamic assessment strategies in the process of teaching collocations. The results of the collocation pretests and posttests gained from the experimental and control groups indicated that dynamic assessment through mediated learning experience promoted collocation knowledge of the students in the experimental group.

本論は、イラン人の中級下EFL (外国語としての英語)学習者間における 連語の一致と不一致の学習をダイナミック・アセスメント（第2言語習得 の実践的評価法の1つとして、学習者の学習可能性に注目して評価する 方法)の効果を検証する。女子学生40人がこの研究に参加した。実験群 は、連語を学習する過程でダイナミック・アセスメントの方略を学習した。 実験群と比較群を対象とした実験の前と後のテストの結果から、学習者 間で教え合うことで学習効果が上がることがわかった。

dramatic surge in the number of studies on vocabulary acquisition over the years reflects the continued importance of teaching and learning vocabulary in ELT contexts (see Schmitt, 2008). Without appropriate knowledge of vocabulary, language users would be in serious communicative trouble and cannot use the four language skills effectively. It follows that learning new words involves acquiring various dimensions of vocabulary knowledge. Vocabulary knowledge, according to Read (2000), entails breadth and depth, with breadth the quantity of words known (i.e., how many words one knows) and depth the quality of word knowledge (i.e., how well one knows a word).

More specifically, as Nation (2001, p. 27) argues, vocabulary knowledge is defined as knowing the words in terms of their form, meaning, and use, both receptively and productively. The components of vocabulary knowledge have been explored in a wide range of studies using various assessment scales (see Nation, 2011 and Read, 2012). Among these components, the use of formulaic language such as lexical bundles and collocations has received particular attention by researchers (González-Fernández \& Schmitt, 2015; Peters, 2015).

\section{Collocation Knowledge}

Perceived as "lexical patterning," the term collocation is defined as "the tendency of two or more words to co-occur in discourse" (Schmitt, 2000, p. 76). This tendency is influenced by the frequency of the word combinations, language users' habitual formation of the word combinations, exclusiveness of a combination and semantic phraseological regulations (see Schmitt, 1998). Collocations can be viewed on a continuum according to their frequency (the number of times they occur in a corpus) and exclusiveness (whether the words in a combination are exclusively used together) - see González-Fernández \& Schmitt (2015).

Collocations are further categorized into congruent and incongruent groups. Based on cross-linguistic relationships and differences, Yamashita and Jiang (2010, pp. 649-650) make a distinction between congruent collocations (collocations that include lexical components that are similar in L1 and L2) and incongruent collocations (collocations that contain lexical components that are different in the two languages). According to Yamashita and Jiang, the influence of $\mathrm{L} 1$ on the acquisition of collocations is due to the cross-linguistic differences and flexible nature of word combinations. In their study on the congruency effect of collocations, Yamashita and Jiang (2010) found that learning incongruent collocations takes a long time, requires high amounts of exposure, and is more difficult. This finding is indicative of the importance of further exploring congruent and incongruent collocations in second or foreign language settings. For more on exploring congruency effects and interlexical effects such as collocate-node 
relationship and word length in the process of collocation acquisition see Peters (2015).

\section{Dynamic Assessment and Vocabulary Instruction}

Dynamic assessment (DA) is derived from $\mathrm{Vy}$ gotskian sociocultural theory. Contributing to a great extent to the integration of assessment and instruction, dynamic assessment places the focus on promoting the learners' abilities through making use of mediating strategies adapted to the needs of the learners in a dynamic and continuous process (Poehner, 2008). The pedagogical significance of dynamic assessment lies in the fact that it "overcomes the assessment-instruction dualism by unifying them according to the principle that mediated interaction is necessary to understand the range of an individual's functioning but that this interaction simultaneously guides the further development of these abilities" (Poehner, 2008, p. 24).

What distinguishes dynamic assessment and the classical types of assessment, Poehner argues, is the sensitivity to the learners' Zone of Proximal Development (ZPD) that is the difference between the learners' "unassisted and assisted performance" (Vygotsky, 1978, p. 86 as cited in Poehner, 2008, p. 14). A dynamic assessment perspective on vocabulary teaching and learning engages the teacher and students in a more organic and dynamic process through which the learners' potentials and differences will become an asset for their development in an interactive system.

Taking the example of vocabulary learning, we can think of a range of possibilities for helping the learners to develop their vocabulary knowledge by implementing dynamic assessment in the classroom. In this process, results of the assessment of the learners' performance and their affordances, limitations, and potentials, inform the teacher to determine how further help needs to be at hand so that the learners will be able to achieve the learning outcome in a more efficacious manner.

By and large, although the role of dynamic assessment within the context of developing language skills has received attention in the field of language teaching (see Poehner, 2008), little research has been conducted to explore dynamic assessment in the context of vocabulary learning with a particular focus on collocations. The main motive behind the present study comes from research findings that support the use of dynamic assessment as an effective method to enhance interaction-based learning growth and learner performance with regard to different language skills (see Anton, 2009).

\section{The Study}

The purpose of this study was to investigate the feasibility of implementing dynamic assessment to develop language learners' collocation knowledge with regard to two categories of collocations, that is, congruent and incongruent collocations. To this purpose the following research questions and null hypotheses were addressed:

RQ1. Is there any statistically significant difference between the effects of DA as compared to static assessment on a better learning of congruent collocations among EFL learners?

RQ2. Is there any statistically significant difference between the effects of DA as compared to static assessment on a better learning of incongruent collocations among EFL learners?

The study utilized a quasi-experimental twogroup pretest-posttest design. Selecting a nonprobability sample of students, we collected data from a control group and an experimental group in a testteach-test cycle.

\section{Participants}

Forty female Iranian students (native speakers of Persian) at an English Language Institute in Tehran participated in the study. The participants' level of proficiency was lower-intermediate based on their level in the institute. However, to homogenize them in terms of language ability using a standard test, we administered the Oxford Placement Test (OPT). Initially, 62 students (out of a total population of 90 students) attended the test. Based on the results of the test, forty students were proven to be at the lower intermediate level. They were in the 18-30 age range. The participants had enrolled in the language institute for the purpose of attending the general English program. Before the study started, the participants had attended the English language program for 6 three-month semesters (i.e., they successfully passed three basic and three elementary levels and thus, could make it to the lower intermediate level.)

\section{Instruments}

The instruments used in this study included the Oxford Placement Test 1 (Allan 2004) and two collocation tests.

\section{The Oxford Placement Test}

In order to ensure the homogeneity of the students in terms of their English language ability, the 
Oxford Placement Test (OPT) was administered at the outset of the study. The OPT provides reliable scores from level A1 upwards based on the Common European Framework of Reference (CEFR) levels. The test is divided into two main sections, listening and grammar, each with 100 items. According to the OPT marking kit and user's guide, the participants who scored between 120 and 134 were considered lower intermediate and were selected for the purpose of the study.

\section{Collocation tests}

Two tests of collocations, developed by the researchers, (a test of congruent collocations and a test of incongruent collocations) were administered as pretests and posttests. The pretests and posttests were the same. The Congruent Collocation Test (CCT) and the Incongruent Collocation Test (ICT) included 20 multiple choice questions each. The questions were intended to check the participants' knowledge of congruent and incongruent collocations. The main criteria for selecting the collocations was the presence of the equivalent word combination in Persian for the CCT and lack of the equivalent combination in Persian for the ICT. Having referred to several collocation dictionaries, we first prepared two lists, one of 60 congruent collocations and one of 60 incongruent collocations. For each collocation, the Persian equivalent was also included in the list. We checked the collocations through expert review. In doing so, two active ELT researchers (PhD holders) reviewed the list and rated the collocations with regard to their difficulty level, appropriateness for the low intermediate level, and their match to the Persian language counterpart. This process produced an initial list of 68 collocations with 34 congruent and 34 incongruent collocations. These collocations were used to develop the first draft of the tests. We piloted the first version of the tests using a sample of 24 low intermediate students, analyzed the items, and revised the tests. The revised tests included 20 items each. The reliability coefficients for the tests were estimated using KR-21 formula and were .75 for the CCT and .70 for the ICT. Sample items from the test can be seen below:

\section{Congruent Collocation Test (sample item):}

Last night a fatal road accident between two cars travelling in the same direction.
A) appeared
B) arose
C) occurred

D) I don't know

\section{Incongruent Collocation Test (sample item):}

Because of the high registration fee, we think a limited number of graduate students will part in the conference.
A) take
B) attend
C) make
D) I don't know

\section{Procedure}

At the outset of the study, the students were homogenized using the OPT. Then, they were divided into two groups, an experimental and a control group, each with 20 students. Both experimental and control groups were given the pretests first. After the pretests, the control group received vocabulary instruction through a common traditional method. Utilizing this method, the teacher taught and assessed collocations through textbook activities such as providing the class with definitions, presenting examples, and doing fill-in-the-blank and matching activities.

The control group attended class for seventeen 45-minute sessions over an eight-week period and covered a total of 68 collocations (34 congruent and 34 incongruent collocations, with four collocations each session) through the traditional method. The experimental group, whose instructor-assessor was the second author of the present paper, received treatment through a seventeen-session dynamic assessment cycle that took approximately 8 weeks. Each session took about 45 minutes. During this period of time, a total of 68 collocations (34 congruent and 34 incongruent collocations, with four collocations a session) were presented. The experimental group's collocation list was the same as that of the control group's. The collocations on this list were chosen from the preliminary list of 120 collocations generated through using expert judgment. Mention must also be made that by the term strategy, in this context, we mean meditation strategies. The meditation strategies included a plan of action with a series of teaching techniques to help the instructor-assessor go through the dynamic assessment process in a systematic way.

\section{Treatment: Strategies Booklet}

To guide the mediation between the instructorassessor and the learners, the instructor used a strategy booklet. The strategy booklet provided the 
mediation strategies in a systematic and continuous sequence from the most implicit to the most explicit. This mediation process consisted of three phases:

1. Presenting the strategies and providing the learners with some definitions, examples, and activities utilizing the strategy

2. Applying the strategies and hints, moving from the most implicit to the most explicit

3. Assessing the type and number of hints required by the learners to respond appropriately to the items

Note should be made that providing definitions and examples was the same for both the control and experimental groups. What made the mediation process different was the nature of interaction. The control group received a teacher-fronted presentation of the definition.

The learners in the experimental group, on the other hand, were engaged in teacher-student interaction cycles to conduct the first phase. This involved a familiarization process. The instructor explained each strategy she was going to use. The students were further provided with several examples to become more familiar with the strategy in question. Receiving help from the teacher, they were encouraged to ask questions to familiarize themselves with the strategies.

In the second phase, the students were engaged in activities focusing specifically on congruent and incongruent collocations during the mediation period. The strategies and hints used during the instruction were categorized from the most implicit to the most explicit. First, the most implicit hints such as retrieval, use of contextual information, or grammatical clues were used for the purpose of scaffolding. In case they were not able to do the activity, more explicit hints like using a collocation dictionary were utilized. These strategies are presented below:

- retrieval (first learners understood one item, then they constructed their own interpretations through discussion with peers, finally the item was retrieved and used in an appropriate situation)

- use of contextual information

- use of grammatical clues

- use of synonyms

- making association and using visual memory

- identification of the type of collocation

- use of a collocation dictionary.
In the third phase, the type and number of the hints required by the learners in order to respond appropriately to the items were calculated. For each session of instruction, as the learners were receiving hints from the teacher and getting familiar with strategies, the type and number of the hints required by the learners in order to respond appropriately to the items were calculated. When they could not respond correctly using the mediation strategies, it meant that the scope of the question was beyond their ZPD and the question was skipped. Still, when the strategies helped them to answer correctly it meant that their ability was developing. These strategies were utilized separately for congruent and incongruent collocations.

\section{Data Analysis}

In addition to exploring the data using descriptive statistics, we compared the scores obtained from the two groups by running independent-samples $t$-tests using IBM SPSS Statistics version 21. Prior to the analysis, the assumptions for conducting an independent-samples $t$-test as a parametric test were checked. The assumptions include the use of interval scale, normality of the distribution of the data, and the assumption of equal variances.

\section{Results}

Table 1 presents the descriptive statistics for the two groups' pretest and posttest scores on the collocation tests, specifying the mean scores and standard deviation of the experimental and control groups. Showing relative consistency in the mean scores on the pretests, the descriptive statistics in Table 1 indicate that the learners' scores on the CCT and ICT posttests were higher, being 17.85 and 17.35 (out of the total score of 20) respectively.

To answer the first research question, an independent-samples $t$-test was conducted to compare the mean scores on the CC posttests. According to the result of the $t$-test, the first null hypothesis was rejected, since there was a significant difference in the scores for the experimental $(\mathrm{M}=17.85, \mathrm{SD}=0.81)$ and control $(\mathrm{M}=12.05, \mathrm{SD}=1.27)$ groups on the congruent collocation test: $\mathrm{t}(38)=17.143, \mathrm{p}<.001$. This finding shows that the use of dynamic assessment led to a better learning of congruent collocations.

As for the second research question, an independent-samples $t$-test was used. The result of the $t$-test showed that there was a significant difference between the experimental and control groups' mean scores on the IC posttests, implying that the learners' knowledge of incongruent collocations was 
enhanced through utilizing dynamic assessment in the process of teaching $(\mathrm{t}(38)=22.523, \mathrm{p}<.001)$.

Table 1. Descriptive Statistics for CC and IC Pretests and Posttests

\begin{tabular}{|c|c|c|c|c|}
\hline Test & Group & $N$ & Mean & $S D$ \\
\hline \multirow{2}{*}{$\begin{array}{l}\text { Con. } \\
\text { Collocation } \\
\text { Pretest }\end{array}$} & Control & 20 & 11.4 & 1.35 \\
\hline & Experimental & 20 & 12.1 & 1.41 \\
\hline \multirow{2}{*}{$\begin{array}{l}\text { Con. } \\
\text { Collocation } \\
\text { Posttest }\end{array}$} & Control & 20 & 12.05 & 1.27 \\
\hline & Experimental & 20 & 17.85 & 0.81 \\
\hline \multirow{2}{*}{$\begin{array}{l}\text { Incon. } \\
\text { Collocation } \\
\text { Pretest }\end{array}$} & Control & 20 & 7.9 & 1.51 \\
\hline & Experimental & 20 & 8.75 & 1.61 \\
\hline \multirow{2}{*}{$\begin{array}{l}\text { Incon. } \\
\text { Collocation } \\
\text { Posttest }\end{array}$} & Control & 20 & 8.6 & 1.46 \\
\hline & Experimental & 20 & 17.35 & 0.93 \\
\hline
\end{tabular}

\section{Discussion}

The main purpose of this study was to explore the effect of dynamic assessment on the learning of congruent and incongruent collocations among low-intermediate EFL learners. The results obtained from the small-scale experiment demonstrated that dynamic assessment led to a better learning of both congruent and incongruent collocations. Having experienced a mediational process of learning collocations, the learners in the experimental group were more successful in learning the congruent and incongruent collocations as compared to the participants in the control group. This result simply echoes the general view that the implementation of dynamic assessment through the use of mediating prompts can significantly enhance the quality of L2 learning (Compernolle \& Williams, 2013).

The scores on the CC and IC pretests and posttests suggest that, in the context of the present study, the learners' ability to use congruent and incongruent collocations was relatively consistent. Although Yamashita and Jiang (2012) found that congruent collocations are less problematic for the learners, the findings of the present study showed that the learners' performance on the CC and IC tests was not markedly different for either pretests and posttests.

\section{Pedagogical Implications}

The present study, although small in scale, together with findings from previous research, can help us draw out a number of implications for ELT teachers.
First, ELT teachers can make appropriate use of dynamic assessment strategies for the purpose of teaching collocations more effectively. To do so, they can utilize mediational strategies through the use of implicit and explicit procedures to improve the quality of teaching collocations.

Next, taking the role of instructor-assessor and providing ongoing feedback, ELT teachers can create an interactive environment, in which they can help students discover their affordances and limitations for acquiring both congruent and incongruent collocations.

Furthermore, taking into account cross-linguistic differences, ELT teachers can make a distinction between the differences between congruent and incongruent collocations. Making appropriate cross-linguistic comparisons, they can make effective use of $\mathrm{L} 1$ as a form of mediational strategy for helping the learners develop deeper and broader knowledge of congruent collocations.

Finally, the appropriate use of L2 combined with relevant instructional materials can be realized in the form of creative instructional strategies to mediate the learners' acquisition of incongruent collocations.

Overall, the findings of the present small-scale study suggest that utilizing dynamic assessment for the purpose of teaching both congruent and incongruent collocations can have a positive effect on the learning outcomes.

\section{References}

Allan, D. (2004). Oxford placement test 1. Oxford: Oxford University Press.

Anton, M. (2009). Dynamic assessment of advanced second language learners. Foreign Language Annals, 42(3), 576-598.

Compernolle, R. A. \& Williams, L. (2013). Editorial: Sociocultural theory and second language pedagogy. Language Teaching Research, 17(3), 277-281.

González-Fernández, B. \& Schmitt, N. (2015). How much collocation knowledge do L2 learners have? The effects of frequency and amount of exposure. International Journal of Applied Linguistics, 166(1), 94-126.

Nation, I. S. P. (2001). Learning vocabulary in another language. Cambridge: Cambridge University Press.

Nation, I. S. P. (2011). Research into practice: Vocabulary. Language Teaching, 44(4), 529-539.

Read, J. (2000). Assessing vocabulary. Cambridge: Cambridge University Press.

Read, J. (2012). Research timeline: Second language vocabulary assessment. Language Teaching, 46(1), 41-52. 
Peters, E. (2015). The learning burden of collocations: The role of interlexical and intralexical factors. Language Teaching Research, 20(1), 113-138.

Poehner, M. (2008). Dynamic assessment: A Vygotskian approach to understanding and promoting $L 2$ development. Berlin: Springer.

Schmitt, N. (1998). Measuring collocational knowledge: Key issues and an experimental assessment procedure. I.T.L. Review of Applied Linguistics, 119-120, 27-47.

Schmitt, N. (2000). Vocabulary in language teaching. Cambridge: Cambridge University Press.

Schmitt, N. (2008). Instructed second language vocabulary learning. Language Teaching Research, 12(3), 329-363.

Yamashita, J. \& Jiang N. (2010). L1 influence on the acquisition of L2 collocations: Japanese ESL users and EFL learners acquiring English collocations. TESOL Quarterly, 44(4), 647-668.

\section{Hiroshima JALT 2017 Conference}

Sunday, 3 December 2017

$$
\text { 9:00 - 17:00 }
$$

Theme: Teaching Language and Culture in a Global Era

With research- and practice-oriented presentations, product/technique demonstrations, a symposium featuring local experts on International Education, and plenty of time to socialize (including a dinner party at a nearby restaurant the night before), there is sure to be something for everyone.

\section{https://sites.google.com/view/ hijalt2017conference/home}

\section{Try be a GREEN JALTER}

\section{Return your conference badge}

2. Remember the 4 R's

3. Bring your own toothbrush, chopsticks, notebook, pen, and water bottle

4. Eat a vegetarian meal

5. Think GREEN!
Mohammad R. Hashemi is Assistant Professor of Applied Linguistics at Kharazmi University, Tehran, Iran. His current research interests include mixed methods research in applied linguistics and language teacher professionalism. He has published papers in international journals including Applied Linguistics, The Modern Language Journal, and Journal of Mixed Methods Research.

Raziye Eskandari holds an MA in Applied Linguistics and is currently working as an EFL teacher in different language institutes in Tehran. Her main areas of research interest include language assessment, dynamic assessment, and discourse and language cognition.
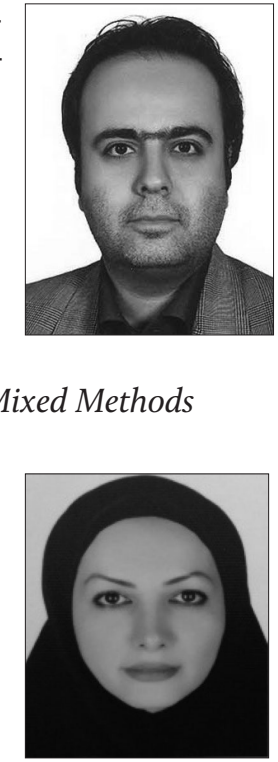

\section{The Linguistic Landscape Forum} Saturday, 9 December $2017 \cdot 13: 30-16: 30$

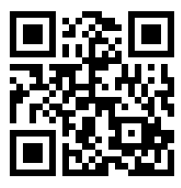

- Location: Rikkyo University Ikebukuro Campus, Building 14, Room (TBA) - 171-8501 Tokyo, Toshima, Nishiikebukuro 3-34-1 • 干171-8501東京都豊島区西池袋3-34-1

- Access: http://english.rikkyo.ac.jp/access/ ikebukuro/direction/

- Fee: Free for members \& Rikkyo Faculty, 1000 yen for non-members; Tokyo JALT membership is available for 3000 yen per year (1500 yen for ALTs/JETs/full-time students)

- RSVP: bit.ly/TJALTDec2017

Join international and Japan-based presenters who will discuss their recent research about and teaching of linguistic landscapes (LL). The 2017 Forum will feature Dr. Christian Ludwig (University of Education Karlsruhe, Germany), Dr. Sender Dovchin (University of Aizu), Dr. Hitomi Yoshio (Waseda University) and Steven Karl (Waseda University/University of Tokyo/Florida International University). 